\title{
Diet quality and diet selection of steers grazing in a rotational system at four levels of forage allowance on a rangeland 1
}

\author{
L Piaggio 2, ER Prates ${ }^{3}$, C Rinaldi ${ }^{4}$, P Soca ${ }^{4}$ \\ 1Part of the Doctoral Thesis of the 1st author, UFRGS, Brasil ; 2 Facultad de Agronomia, Avda Garzón 780 , \\ Montevideo, Uruguay; 3UFRGS, Avda Bento Gonçalves 7712, Porto Alegre, RS, Brasil ; ${ }^{4 E E M A C .,}$ \\ Facultad de Agronomia, $\mathrm{km} 373$, Paysandú, Uruguay
}

A grazing experiment was conducted on a rangeland (mainly Stypa ssp, Paspalum ssp) oversowed with Lotus corniculatus $L$. at the Experimental Agronomic Station EEMAC, Uruguay, to study diet quality and to provide an understanding of how the rapid defoliation that occurs under rotational grazing affects diet selection. Four levels of forage allowance were evaluated : $5.0 ; 7.5 ; 10.0$ and $12.5 \mathrm{~kg} \mathrm{DM} / 100$ $\mathrm{kg} L W /$ day, using 24 yearlings Holstein steers as fixed experimental animals. Forage allowance was adjusted using the Put and Take technique in a rotational grazing system, ( 7 grazing days and 35 days resting period), using 6 paddocks for each treatment. Diet were collected from all treatments on 10 occasions over 9-month period (winter, spring, summer) using 5 esophageacally fistulated steers. Dietary quality was assessed on the 1st, 4th and 7 th grazing day determining crude protein (CP), in vitro organic matter digestibility (IVOMD) and neutral detergent fiber (NDF) of extrusa samples in each collection. Biting rate (BR, mean number of bites during $1 \mathrm{~min}$, measured on three times per collection) and bite weight ( $\mathrm{BW}$, dry weight of extrusa collected divided by the number of bites taken per collection) were measured concurrently. Diet selection was assessed by difference of forage available quality and extrusa quality on the $1 \mathrm{st}$ grazing day.

Season was the main effect on the pasture quality, and diet quality reflected seasonal variation, with the lowest values during winter (47.91\% IVOMD, $13.65 \%$ CP, $67.22 \%$ NDF) and the greatest values during spring $(62.36 \%$ IVOMD, $18.53 \%$ CP, $59.06 \%$ NDF). Diet quality was greater than pasture quality with mean differences of $7.66(P<0.01), 3.67$ $(P<0.01)$ and -2.20 (NS) percent units for IVOMD, CP and NDF, respectively. Selection degree was greater with greater forage allowance (Table 1).There were large changes in diet quality and ingestive behaviour along the grazing period. Diet quality declined significantly from the 1 st to the 4th grazing day (Table 2). Ingestion rate ( $\mathrm{R}=\mathrm{BR} \times \mathrm{BW})$ also declined during the grazing period (Table 2).

Results showed that animal selection is a powerful mechanism to improve diet quality until forage availability fall under a critic value. This limit appears to be lower for protein than for metabolizable energy estimated from IVOMD. Nevertheless animal selection is not as an important factor as season in determining diet quality under rangeland conditions.

Table 1

\begin{tabular}{|c|c|c|c|c|c|c|}
\hline \multirow{2}{*}{$\begin{array}{l}\text { Forage allowance } \\
(\mathrm{kg} \mathrm{DM} / 100 \mathrm{~kg} \mathrm{LW} / \mathrm{d})\end{array}$} & \multicolumn{3}{|c|}{ percent unit differences } & & & \\
\hline & IVOMD & $\mathrm{CP}$ & NDF & & & \\
\hline $\begin{array}{l}5.0 \\
7.5 \\
10.0 \\
12.5\end{array}$ & $\begin{array}{c}5.78 \\
4.72 \\
8.59^{\star} \\
11.03^{* *}\end{array}$ & $\begin{array}{c}1.70 \\
3.42^{\star} \\
4.09^{\star \star} \\
4.99^{\star *}\end{array}$ & $\begin{array}{c}0.86 \\
-2.40 \\
-1.67 \\
-4.97\end{array}$ & & & \\
\hline \multicolumn{7}{|l|}{$\begin{array}{l}{ }^{*} \mathrm{P}<0.05 ;{ }^{* *} \mathrm{P}<0.01 \\
\text { Table 2: }\end{array}$} \\
\hline Grazing day & $\begin{array}{l}\text { IVOMD } \\
(\%)\end{array}$ & $\begin{array}{l}\mathrm{CP} \\
(\%)\end{array}$ & $\begin{array}{l}\text { NDF } \\
(\%)\end{array}$ & $\begin{array}{c}\text { BW } \\
\text { (mg OM) }\end{array}$ & $\underset{(\mathrm{n} / \mathrm{min})}{\mathrm{BR}}$ & $\stackrel{\mathrm{IR}}{(\mathrm{mg} \mathrm{OM} / \mathrm{h})}$ \\
\hline $\begin{array}{l}1 \\
4 \\
7\end{array}$ & $\begin{array}{c}56.3^{\mathrm{a}} \\
53.07 \mathrm{~b} \\
53.41^{\mathrm{b}}\end{array}$ & $\begin{array}{l}18.03^{a} \\
14.56^{b} \\
14.28^{b}\end{array}$ & $\begin{array}{l}60.46^{\mathrm{a}} \\
63.29^{\mathrm{b}} \\
67.52^{\mathrm{c}}\end{array}$ & $\begin{array}{l}306^{a} \\
168^{b} \\
159^{b}\end{array}$ & $\begin{array}{l}47^{a} \\
43^{a} \\
36^{b}\end{array}$ & $\begin{array}{l}785^{a} \\
395^{b} \\
293^{b}\end{array}$ \\
\hline
\end{tabular}

$a, b, c:$ means with different superscripts are differents $(P<0.05)$ 